\title{
Protective Effects of Selenium and Alpha-Tocopherol against Lead- Induced Hepatic and Renal Toxicity in Oreochromis Niloticus
}

\section{Shimaa A Elgaml ${ }^{\text {* }}$, Ryad Khalil ${ }^{2}$, Emad A Hashish ${ }^{1}$ and Abdelhakeem El-Murr ${ }^{3}$}

${ }^{1}$ Department of Clinical Pathology, Faculty of Veterinary Medicine, Zagazig University, Zagazig, Egypt

${ }^{2}$ Department of Poultry and Fish diseases, Faculty of Veterinary Medicine, Alexandria University, Egypt

${ }^{3}$ Department of Fish Diseases and Management, Faculty of Veterinary Medicine, Zagazig University, Zagazig, Egypt

\begin{abstract}
Lead is a serious poison causing serious injury or death. Current study was designed to investigate the potential protective effect of selenium (Se) and alpha-tocopherol (alpha-toc) against the hepatic and renal toxicity of lead acetate in Oreochromis niloticus. Two hundred and twenty five $O$. niloticus were divided into five groups; control, lead acetate treated $(73.40 \mathrm{mg} / \mathrm{liter}$ ), Se treated (4 mg sodium selenite/ $\mathrm{kg}$ diet), alpha-toc treated $(200 \mathrm{mg} / \mathrm{kg}$ diet) plus $\mathrm{Se}+$ alpha-toc co-treated groups for 10 weeks. Levels of aspartate aminotransferase (AST), alanine transaminase $(A L T)$, total protein, urea, creatinine, calcium $(\mathrm{Ca})$, inorganic phosphate $(\mathrm{P})$, magnesium $(\mathrm{Mg})$, superoxide dismutase (SOD), reduced glutathione (GSH) and the lipid peroxidation index (MDA) were determined The results revealed an increase in the levels of liver enzymes, urea, creatinine and MDA; meanwhile, the total protein, $\mathrm{Ca}, \mathrm{P}, \mathrm{Mg}, \mathrm{SOD}$ and GSH were decreased. Therefore, it could be concluded that selenium (Se) and alpha-tocopherol (alpha-toc) may be useful tool to minimize the toxic effects of lead toxicity by its potent antioxidant activity.
\end{abstract}

Keywords: Alpha-toc; Lead acetate; Oreochromis Niloticus; Oxidative stress; Selenium

\section{Introduction}

In developing countries, aquatic animals are continuously exposed to heavy metals which threaten the aquatic ecosystems through their oxidative stress. Water pollution resulted from several factors such as mining and disposal of metal industry effluents. High levels of non biodegradable and not eliminated heavy metals accumulated in fish resulted in toxicity, affect fish metabolism and physiology [1]. Lead is a toxic heavy metal accumulated in the ecosystem with a dangerous effect on freshwater fish [2]. It is extensively accumulated in the liver and kidney, causing hepatic and renal toxicity [3]. Aquatic organisms receiving water-borne contaminants induce oxidative stress, generating free radicals and reactive oxygen species (ROS), causing oxidative damage and finally cell death $[4,5]$.

Antioxidants play an important role in maintaining the fish redox status inside tissues and cells. Insufficient antioxidants predispose to oxidative stress. Antioxidant in aquatic system is considered as an important biomarker of exposure to different environmental pollutants [6]. Lead enhances the intracellular oxidative stress leading to the formation of reactive oxygen species causing alteration in the physiological state of the fish.

Selenium (Se) plays an important role in the cellular oxidative defense induced by oxidative stress and considered one of the most essential antioxidants [7,8]. Alpha-toc has an important role in immune enhancement, and antioxidant activity; it protects the body cells from the harmful effects of free radicals which produced during normal cellular activity and several stressors [9]. Alpha-toc maintains the structural integrity of the cell membrane of important immune cells, thus enhances the fish immunity and antioxidants activity $[10,11]$. Selenium and alpha-toc are natural antioxidants, which usually found in the food of animal and human. Selenium is predominantly supplemented in human's food from fish [12], a-toc is a natural antioxidant found in human and animal's food [13].

It was reported that administration of Se or alpha-toc would play an important role to prevent the oxidative degradation [14]. Consequently, the aim of the present study was to investigate the hepatic and renal protective effect, by examining the potential antioxidant role of Se and alpha-toc treatment or co-treatment against the oxidative damage induced by lead toxicity in Oreochromis niloticus.

\section{Material and Methods}

\section{Chemicals}

Sodium selenite, (4 $\mathrm{mg} / \mathrm{kg}$ dry diet), supplied from $\mathrm{BDH}$ Laboratory reagents. Ltd, Poole, England [15], diluted in 8\% corn oil. Each $1 \mathrm{ml}$ of the preparation contains $1.67 \mathrm{mg}$ Sodium Selenite. Vitamin E (alpha-tocopherol 95.5\%), $200 \mathrm{mg} / \mathrm{kg}$ dry diet [16] diluted in $8 \%$ corn oil, Sigma-Aldrich Co. LLC. Lead acetate obtained from El-Nasr Pharmaceutical Chemical Company, Egypt. Toxic dose for induction of lead toxicity in O. niloticus was $1 / 20$ of LC50 $(73.40 \mathrm{mg} / \mathrm{L})$ [17]

\section{Fish maintenance}

Cultured O. niloticus, purchased from the central laboratory for Aquaculture and fisheries, Abbassa, Egypt with an average body weight $100 \pm 10 \mathrm{~g}$ each and 4 to 5 months of age. Fish were kept in glass aquaria $(80 \mathrm{~cm} \times 40 \mathrm{~cm} \times 30 \mathrm{~cm}$ ) with sufficient and continuous aeration (oxygen concentration of $6.20 \mathrm{mg} / \mathrm{L}$ ) using an electric air pump compressor, dechlorinated tap water, $\mathrm{pH}$ value of 7.5 and an alkalinity of 340 $\mathrm{mg} / \mathrm{L} \mathrm{CaCO}_{3}$. Fish were acclimatized for two weeks before starting the experiment, temperature was adjusted at $24 \pm 2 \mathrm{C}$ using heater

*Corresponding author: Shimaa AE, Department of Clinical Pathology, Faculty of Veterinary Medicine, Zagazig University, Zagazig, Egypt, Tel: 002-055-228-3683 E-mail:drshimaa_68@yahoo.com

Received November 17, 2014; Accepted December 10, 2014; Published January 12, 2015

Citation: Elgaml SA, Khalil R, Hashish EA, El-Murr A (2015) Protective Effects of Selenium and Alpha-Tocopherol against Lead-Induced Hepatic and Renal Toxicity in Oreochromis Niloticus. J Aquac Res Development 6: 299. doi: 10.4172/2155-9546.1000299

Copyright: (c) 2015 Elgaml SA, et al. This is an open-access article distributed under the terms of the Creative Commons Attribution License, which permits unrestricted use, distribution, and reproduction in any medium, provided the original author and source are credited. 
Citation: Elgaml SA, Khalil R, Hashish EA, El-Murr A (2015) Protective Effects of Selenium and Alpha-Tocopherol against Lead-Induced Hepatic and Renal Toxicity in Oreochromis Niloticus. J Aquac Res Development 6: 299. doi:10.4172/2155-9546.1000299

Page 2 of 5

(CMI, Germany) and the water was daily renewed to maintain good water quality. The fish were fed on a balanced pellet diet during the acclimation period, commercial diet composed of $32 \%$ crude protein, $10 \%$ Ether extract, $10 \%$ moisture, $13 \%$ ash, $4.5 \%$ fiber and $3200 \mathrm{~K}$. cal., purchased from Hendrix Misr for Animal Nutration, Egypt.

\section{Study design}

Five groups of two hundred and twenty five O. niloticus were used in the current study for 10 successive weeks and divided as following:

- Group I $(\mathrm{n}=45)$, negative control, O. niloticus were fed on basal diet with clean water and left under normal condition without any treatment.

- Group II ( $\mathrm{n}=45)$, positive control, lead acetate group, $O$. niloticus were fed on basal diet and daily exposed to $73.40 \mathrm{mg}$ lead acetate/liter in a concentration of $0.26 \%$ added to water for 10 weeks after a complete change of water.

- $\quad$ Group III ( $\mathrm{n}=45)$, O. niloticus were fed on diet mixed with sodium selenite in a dose of $4 \mathrm{mg} / \mathrm{kg}$ dry diet (diluted in $8 \%$ corn oil) daily for one week. Fish were exposed to lead acetate $73.40 \mathrm{mg} /$ liter in water and receive sodium selenite treated diet for the next successive 9 weeks.

- Group IV ( $\mathrm{n}=45)$, O. niloticus were fed on diet mixed with alpha-toc in a dose of $200 \mathrm{mg} / \mathrm{kg}$ dry diet (diluted in $8 \%$ corn oil) daily for one week. Fish were exposed to Lead acetate $73.40 \mathrm{mg} / \mathrm{liter}$ in water and receive alpha-toc treated diet for the next successive 9 weeks.

- Group V ( $\mathrm{n}=45)$, O. niloticus were fed on diet mixed with sodium selenite and alpha-toc ( 4 and $200 \mathrm{mg} / \mathrm{kg}$ dry diet respectively) daily for one week. Fish were exposed to Lead acetate $73.40 \mathrm{mg} /$ liter in water for one week and receive a mixed diet of Sodium selenite and alpha-toc for the next successive 9 weeks.

Experimental procedures were carried out at the Faculty of Veterinary Medicine, Alexandria University, Egypt. The experiment was complied with the Animal Welfare Act and was approved by the Alexandria University's Veterinary Committee. O. niloticus were scarified by transaction of the spinal cord at the end of the experimental period. Samples were collected on a three replicates and immediately collected for laboratory analysis.

\section{Blood collection and preparation}

Blood samples were collected at the end of the experiment (10th week). Benzocaine anesthetic solution $(1 \mathrm{~g} / 10 \mathrm{~L}$ ) was used and the blood was collected using sterile needles and syringe from the caudal vessels. Blood was collected into a clean glass tubes and left to clot for 2 hours at room temperature then centrifuged (BOECO centrifuge, Germany) at $3000 \mathrm{rpm}$ for 15 minutes. Sterile Pasteur pipettes (SigmaAldrich) were used to collect the serum supernatant and transferred to dry, labeled Eppendorf tubes for different biochemical analysis.

\section{Biochemical assays}

Semi-automated Photometer 5010 V5+ (RIELE GmbH \& Co, Berlin, Germany) was used for the biochemical assays with commercial kits bioMérieux, Egypt. Serum hepatic enzymes,(aspartate aminotransferase-AST and serum alanine aminotransferase (ALT) activity [18] and Serum total protein [19]. Kidney markers such as serum urea [20] and serum creatinine [21]. Serum electrolytes such as calcium [22], serum inorganic phosphorus [23] and serum magnesium [24].

\section{Liver and kidney homogenates}

Tissue homogenate preparation was done according to [25] with some modification. Liver and kidney tissue were collected and washed with ice-cold $\mathrm{NaCl} 0.9 \%$ three times. Tissue sample (one gram) were rinsed with $9 \mathrm{ml}$ of normal saline $\mathrm{NaCl} 0.9 \%$ and homogenized using electrical tissue homogenizer, and centrifuged (BOECO centrifuge, Germany) at $3000 \mathrm{rpm}$ for 15 minutes. The supernatant is collected and used for the estimation of antioxidant enzymes such as (SOD and GSH) and MDA.

\section{Determination of Superoxide dismutase (SOD)}

Measuring the SOD activity according to [26], by indirect inhibition assay of reduction of nitro blue tetrazolium (NBT), which was generated by $37.5 \mathrm{mM}$ hydroxylamine in alkaline solution. About $0.5 \mathrm{M}$ sodium carbonate buffer ( $\mathrm{pH}$ 10.2) with $2 \mathrm{mM}$ ethylenediaminetetraacetic acid (EDTA) were used for the reaction. The NBT reduction by superoxide anion to blue formazan was measured at $560 \mathrm{~nm}$, where the NBT reduction rate in the absence of hemolysate was used as a reference. The amount of protein needed to decrease the reference rate to $50 \%$ of maximum inhibition is one unit of SOD.

\section{Determination of reduced glutathione (GSH)}

The activity of GSH was determined based on the development of a yellow color when DTNB (5,5-dithiobis-2nitrobenzoicacid) was added to compounds containing sulfhydryl groups [27]. Tissue homogenate (500 ml) were added to $3 \mathrm{ml}$ of sulfosalicylic acid $4 \%$ and centrifuged at $1600 \mathrm{~g}$ for 15 minutes. The supernatant $(500 \mathrm{ml})$ were collected and added to Ellman's reagent and the absorbance was measured at $412 \mathrm{~nm}$ after10 minutes.

\section{Lipid peroxidation assay}

The concentration of MDA in liver and kidney tissues, an index of lipid peroxidation, was determined spectrophotometrically according to [28]. Lipid peroxidation levels were measured via the thiobarbituric acid color reaction for malondialdehyde (MDA) at $535 \mathrm{~nm}$. The freshly made MDA solution by the hydrolysis of 1,1,3,3-tetramethoxy propane was used as a standard.

\section{Statistical analysis}

Statistical Analysis System software package were used to analyze the data by one-way analysis of variance ANOVA [29] and the significant differences between means were determined at a level of $(\mathrm{P}<0.05)$. Further analysis was carried out. Differences between means were assessed using Tukey's honestly significant difference test for post hoc multiple comparisons. Data are expressed as the mean \pm S.E.

\section{Results}

Evaluation of hepatic marker enzymes and total protein. The effects of lead acetate intoxication as well as the preventive effects of Se and alpha-toc on hepatic marker enzymes and total protein are shown in Figure 1. Significant increases $(\mathrm{P}<0.05)$ in serum liver function marker enzymes (AST, ALT) were recorded in lead acetate intoxicated fish as compared to negative control group. Significant decrease $(\mathrm{P}<0.05)$ in 
serum total protein was also detected in the positive control group. Meanwhile, Se and alpha-toc treated groups showed significant improvement $(\mathrm{P}<0.05)$ in AST, ALT and total protein comparing with positive control. The results indicated that the alpha-toc and se alpha-toc treated groups were more effectively improves the ALT level compared with the other groups.

Evaluation of kidney markers. Similarly, serum urea and creatinine levels showed significant increases $(\mathrm{P}<0.05)$ in lead acetate intoxicated fish compared with the negative control and other treated groups. Significant improvement $(\mathrm{P}<0.05)$ in the serum urea and creatinine levels was recorded in Se and alpha-toc treated groups. Renal function tests data are shown in Figure 2. Results indicated that the improvement in the serum urea and creatinine levels were close in all treated groups when compared with the positive and negative control groups.

Evaluation of serum electrolytes. Changes in the serum calcium $(\mathrm{Ca})$, phosphorus $(\mathrm{P})$ and magnesium $(\mathrm{Mg})$ were recorded in Figure 2. Lead acetate intoxicated fish showed significant decrease $(\mathrm{P}<0.05)$ in serum $\mathrm{Ca}, \mathrm{P}$ and $\mathrm{Mg}$ levels compared with the negative control. Se and alpha-toc treated groups ameliorates the lead intoxication changes in the studied serum parameters. Significant improvement $(\mathrm{P}<0.05)$ in the serum $\mathrm{Ca}, \mathrm{P}$ and $\mathrm{Mg}$ level was observed. The results indicate that the $\mathrm{Se}$ and alpha-toc co-treatment group effectively improves the electrolyte level close to the normal level compared with the other treated groups and the negative control group.

Evaluation of hepatic and renal lipid peroxidation. Lead acetate intoxication effect as well as preventive effects of Se and alpha-toc on liver and kidney tissue lipid peroxidation parameters is shown in Figure 3. A significant increase $(\mathrm{P}<0.05)$ in liver and kidney MDA were observed in Lead acetate intoxicated group when compared with the control group. Concerning Se and alpha-toc co-treated groups, liver and kidney MDA levels were significantly decreased when compared with the positive control group.

Evaluation of hepatic and renal antioxidant status. Lead acetate intoxication effect as well as preventive effects of Se and alpha-toc on liver and kidney tissue homogenate antioxidant parameters is shown in Figure 3. Significant decrease $(\mathrm{P}<0.05)$ in the in liver and kidney level of SOD and GSH was reported in Lead acetate intoxicated group. On the other hand, liver and kidney SOD and GSH levels were significantly $(\mathrm{P}<0.05)$ increased in Se and alpha-toc treated groups when compared with the positive control group.

\section{Discussion}

In the present study, hepatorenal injuries caused by lead intoxication may be attributed to the oxidative stress resulted from free radical production. Lead is an important toxic metal has great health hazard it doesn't accumulate in any tissues but it absorbed from the gastrointestinal tract into the blood then distributed into different body tissues to be excreted throughout the kidney [30]. Selenium and alpha-toc have a powerful antioxidant activity against via decreasing the oxidative stress that resulted from many environmental pollutants $[13,31]$.

Significant increase in transaminase enzymes (AST and ALT) was detected in lead intoxicated group. Leakage of these enzymes into blood stream may be a result of hepatic dysfunction. An increase in the serum enzymes due to the liver dysfunction after exposing to several toxic metals has been reported [32-34]. Decrease in serum total protein (hypoporotenemia) in intoxicated group has been reported, this might be a result from the loss of protein, which might arise from kidney dysfunction with protein excretion in the urine. Inhibition of the hepatic protein synthesis is also responsible for reducing the synthesis of total protein [35]. Selenium and alpha-toc treated groups showed an improvement in the level of hepatic serum transaminases and total protein. This might be due to the maintained level of membrane-bound enzymes and the activities of antioxidant enzymes near normal levels, emphasizing their effects as antioxidants and preventing enzyme leakage into the circulation $[8,36]$.

An increase in the urea and creatinine levels has been reported in lead intoxicated group, this might be due to the glomerular insufficiency [37], also the increase in the production of reactive oxygen species and kidney injury [38] as a result of lead-induced nephrotoxicity. The elevation of urea and creatinine levels in the blood is an indicative of impaired kidney function [30]. Selenium and alpha-toc supplementation in the diet ameliorate the kidney function. This might attributed to the effective role in the breaking the chain of free radical reactions as it allows free radicals to abstract a hydrogen atom from the antioxidant molecule rather than from polyunsaturated fatty acids

\section{- Group I - Group II \ Group III \ Group IV • Group V}

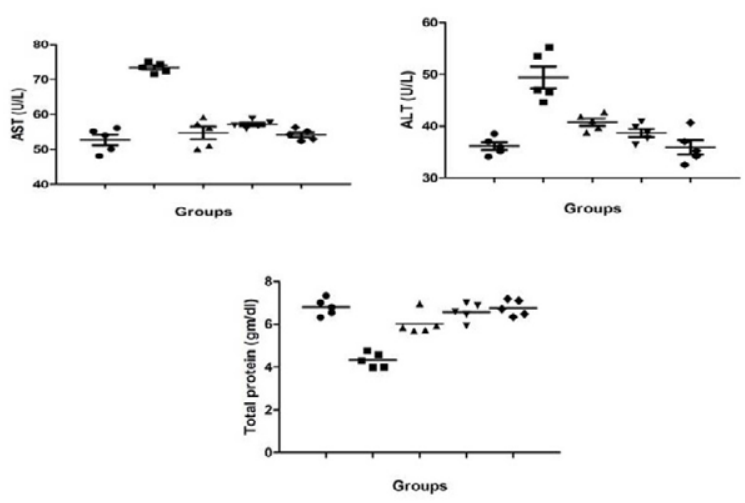

Figure 1: Showing the levels of serum aspartate aminotransferase (AST) $(\mathrm{U} / \mathrm{L})$, alanine amino transferase $(A L T)(\mathrm{U} / \mathrm{L})$ and total protein $(\mathrm{gm} / \mathrm{dl})$ in al treated groups. Values were significantly different at $(P<0.05)$ when compared with the negative control group. Data are expressed as means $\pm S E(n=5)$.
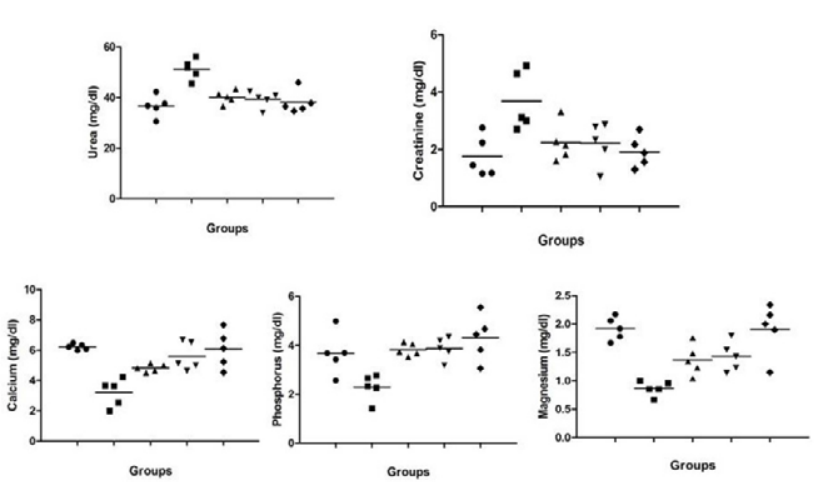

Figure 2: Changes in the levels of serum urea, creatinine and serum electrolytes such as calcium $(\mathrm{Ca} 2+)$, phosphorous $(P)$ and magnesium $(\mathrm{Mg} 2+)$ levels $(\mathrm{mg} / \mathrm{dl})$. Values were significantly different at $(P<0.05)$ when compared with the negative control group. Data are expressed as means $\pm \mathrm{SE}$ $(n=5)$. 
Group I
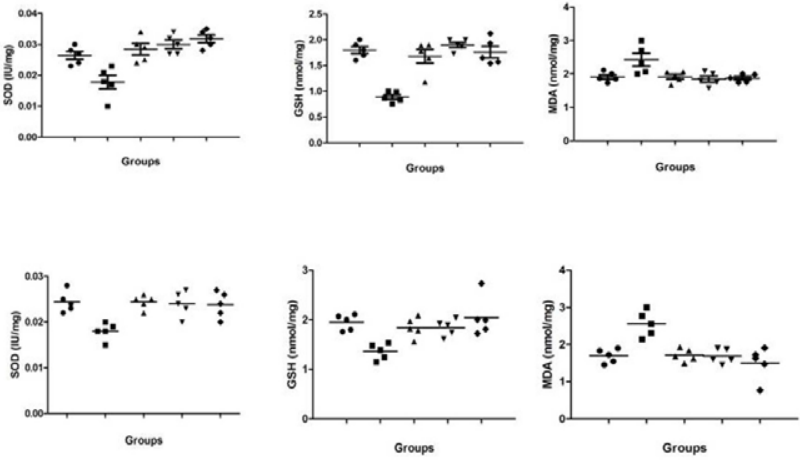

Figure 3: Estimation of hepatic and renal antioxidants such as superoxide dismutase (SOD) $(\mathrm{IU} / \mathrm{mg})$, glutathione peroxidase $(\mathrm{GSH})(\mathrm{nmol} / \mathrm{mg})$ and lipid peroxidation index (MDA) $(\mathrm{nmol} / \mathrm{mg})$. Values were significantly different at $(\mathrm{P}<0.05)$ when compared with the negative control group. Data are expressed as means $\pm S E(n=5)$.

leading to formation of relatively unreactive radicals species to protect the kidney tissue from per-oxidative damage [31,39].

The kidney dysfunction reflected by the reduction of ions reabsorption with enhanced efflux of these ions, renal loss, proximal tubular cells and tubular dysfunction with hypocalcemia and hypophosphatemia [40]. Lead leads to a disturbance in $\mathrm{Ca}^{2+}$ homeostasis, as it leads to disruption of the mechanisms of ion regulation [30] beside its significant effect on the rate of renal $\mathrm{Ca}^{2+}$ reabsorption. The progressive decrease in $\mathrm{Ca}^{2+}$ reabsorption is associated with the significant increase in $\mathrm{Ca}^{2+}$ excretion. Serum $\mathrm{Mg}^{2+}$ showed significant decrease throughout the experimental period. The decrease may be due to the increase in the urinary $\mathrm{Mg}^{2+}$ excretion. Lead might interfere with tubular $\mathrm{Mg}^{2+}$ reabsorption, perhaps in a similar manner with tubular $\mathrm{Ca}^{2+}$ reabsorption. The exact phenomenon is unknown but the decrease in serum $\mathrm{Mg}^{2+}$ may be due to the reduction in net reabsorption efficiency [40]. Selenium and alpha-toc ameliorate this adverse effect, this might attributed to the formation of excreted complexes between lead, selenium and alpha-toc to be removed from the tissue.

Antioxidants play an important role in improving animal health and the defense mechanism [41]. An inhibitory effect of SOD activities leads to impairment of cell antioxidant defenses mechanism that renders cells more exposure to oxidative attacks [42]. Selenium and alphatoc significantly reduce the progressive liver and kidney dysfunction induced by lead oxidative stress [14]. The free radical reactions chain will be breaked after the uptake of hydrogen atom from the antioxidant molecule by the free radicals instead of polyunsaturated fatty acids, resulting in unreactive radical species [14, 43]. A compensatory mechanism against oxidative stress could be due to the increased SOD level which may be due to the antioxidant genes over expression [14].

It is reported that reduced glutathione (GSH) is consumed in the prevention from free radical mediated lipid peroxidation [44] and considered as a biomarker of oxidative stress. Lead decrease the GSH level, where most of the enzymes contain sulfhydryl groups at their active site and become inactive due to direct binding of lead to sulfhydryl group and so several antioxidant enzymes will not able to protect the imbalance between pro-oxidant and antioxidant [14, 45]. Our results indicated that selenium and alpha-toc treatment leading to a significant increase in the activity of GSH with the ability to eliminate the toxic effect of lead. Alpha-toc protects the unsaturated fatty acids of membrane phospholipids from oxidative degeneration through the formation of unreactive radical species and breaking the free radical reactions chain [36]. It is a useful free radical scavenger against stress conditions in several tissues [46]. The increases in selenium-dependent antioxidant enzymes activities decrease free radical-mediated lipid peroxidation and regenerate reduced glutathione.

Initiation of lipid peroxidation and oxidative stress in different tissues is correlated to reactive oxygen species (ROS). Lead toxicity might attributed to its ability to generate reactive oxygen species (ROS), this induce oxidative damage in several tissues and enhancing lipid peroxidation [42]. On the other hand, selenium and alpha-toc were able to protect the kidney against the toxicity from lead acetate, they reduce the elevated MDA level. It has been reported that alpha-toc has the ability to protect against lipid peroxidation through the oxygen scavenging activity, neutralizing the lipid peroxidation and unsaturated membrane lipids [47]. Stimulation of the radical scavenger and the increase in the antioxidant defense mechanism might be the protecting role of selenium against lipid peroxidation [46].

\section{Conclusion}

Lead acetate is a dangerous metal with hepato-nephrotoxic effect. Oxidative stress plays an important role in Lead toxicity. Antioxidants have been proven to be effective in ameliorating lead toxicity. Selenium and alpha-toc are potent antioxidants with the ability to improve general health condition and ameliorate the lead induced oxidative damage. Current study confirms that lead intoxication alterate serum biochemical parameters, lipid peroxidation and inhibit the antioxidant enzymes activity. Thus, it is recommended to focus on supplementation of fish and aquaculture farms with antioxidants such as selenium and alpha-toc to alleviate pollutant stress and improve the fish health and productivity especially in contaminated areas.

\section{References}

1. Scotta GR, Sloman KA (2004) The effects of environmental pollutants on complex? shbehaviour: integrating behavioural and physiological indicators of toxicity. Aquat Toxicol 68: 369-392.

2. Salami IR, Rahmawati S, Sutarto RI, Jaya PM (2008) Accumulation of heavy metals in freshwater fish in cage aquaculture at Cirata Reservoir, West Java Indonesia. Ann NY Acad Sci 1140: 290-296.

3. Luszczek-Trojnar E, Drag-Kozak E, Popek W (2013) Lead accumulation and elimination in tissues of Prussian carp, Carassiusgibelio, after long-term dietary exposure, and depuration periods. Environ Sci Pollut Res Int 20: 3122-3132.

4. Valavanidis A, Vlahogianni T, Dassenakis M, Scoullos M (2006) Molecular biomarkers of oxidative stress in aquatic organisms in relation to toxic environmental pollutants. Ecotoxicol Environ Saf 64: 178-189.

5. Lushchak VI (2011) Environmentally induced oxidative stress in aquatic animals. Aquat Toxicol 101:13-30.

6. Ahmad I, Hamid T, Fatima M, Chand HS, Jain SK, et al. (2000) Induction of hepatic antioxidants in freshwater catfish (Channapunctatus Bloch) is a biomarker of paper mill effluent exposure. Biochim Biophys Acta 1523: 37-48.

7. Monteiro DA, Rantin FT, Kalinin AL (2009) The effects of selenium on oxidative stress biomarkers in the freshwater characid fish matrinxa, Bryconcephalus exposed to organophosphate insecticide Folisuper 600 BR (methyl parathion). CompBiochemPhysiol C Toxicol Pharmacol 149: 40-49.

8. Talas ZS, Orun I, Ozdemir I, Erdogan K, Alkan A, et al. (2008) Antioxidative role of selenium against the toxic effect of heavy metals $(\mathrm{Cd}+2, \mathrm{Cr}+3)$ on liver of rainbow trout (Oncorhynchusmykiss). Fish Physiol Biochem 34: 2 17-222.

9. John S, Kale M, Rathore N, Bhatnagar D (2001) Protective effect of vitamin $E$ in dimethoate and malathion induced oxidative stress in rat erythrocytes. J NutrBiochem 12: 500-504.

10. Montero D, Tort L, Robaina L, Vergara JM, Izquierdo MS (2001) Low vitamin $\mathrm{E}$ in diet reduces stress resistance of gilthead seabream (Sparusaurata) 
Citation: Elgaml SA, Khalil R, Hashish EA, El-Murr A (2015) Protective Effects of Selenium and Alpha-Tocopherol against Lead-Induced Hepatic and Renal Toxicity in Oreochromis Niloticus. J Aquac Res Development 6: 299. doi:10.4172/2155-9546.1000299

juveniles. Fish Shellfish Immunol 11: 473-490.

11. Puangkaew J, Kiron V, Somamoto T, Okamoto N, Satoh S, et al. (2004) Nonspecific immune response of rainbow trout (OncorhynchusmykissWalbaum) in relation to different status of vitamin $E$ and highly unsaturated fatty acids. Fish Shellfish Immunol 16: 25-39.

12. Steinbrenner $H$, Sies $H(2009)$ Protection against reactive oxygen species by selenoproteins. Biochimicaet Biophysica Acta 1790: 1478-1485.

13. Traber MG, Atkinson J (2007) Vitamin E, antioxidant and nothing more. Free Radical Biol Med 43:4-15.

14. Flora SJ, Mittal M, Mehta A (2008) Heavy metal induced oxidative stress \& its possible reversal by chelation therapy. Indian J Med Res 128: 501-523.

15. Atencio L, Moreno I, Jos A, Prieto Al, Moyano R, etal. (2009) Effects of dietary selenium on the oxidative stress and pathological changes in tilapia (Oreochromisniloticus) exposed to a microcystin-producing cyanobacterial water bloom. Toxicon 53: 269-282.

16. Lim C, Yildirim-Aksoy M, Li MH, Welker TL, Klesius PH (2009) Influence of dietary levels of lipid and vitamin $\mathrm{E}$ on growth and resistance of Nile tilapia to Streptococcus iniae challenge. Aquaculture 298: 76-82.

17. Hassanain MA, Abbas WT, Ibrahim TB (2012) Skeletal ossification impairment in Nile Tilapia (Oreochromisniloticus) after exposure to lead acetate. Pak J Biol Sci 15: 729-735

18. Reitman S, Frankel S (1957) A colorimetric method for the determination of serum glutamic oxalacetic and glutamic pyruvic transaminases. Am J Clin Pathol 28: 56-63.

19. Krohn RI (2002) The colorimetric detection and quantitation of total protein Curr Protoc Cell Biol.

20. Tabacco A, Meiattini F, Moda E, Tarli P (1979) Simplified enzymic/colorimetric serum urea nitrogen determination. Clin Chem 25: 336-337.

21. Heinegard D, Tiderstrom G (1973) Determination of serum creatinine by a direct colorimetric method. Clin Chim Acta 43: 305-310.

22. Cohen SA, Sideman L (1979) Modification of the o-cresolphthaleincomplexone method for determining calcium. Clin Chem 25: 1519-1520.

23. Berti G, Fossati P, Tarenghi G, Musitelli C, Melzid'Eril GV (1988) Enzymatic colorimetric method for the determination of inorganic phosphorus in serum and urine. J Clin Chem Clin Biochem 26: 399-404.

24. Smith AJ (1955) A colorimetric method for the estimation of serum magnesium Biochem J 60: 522-527.

25. Huculeci R, Dinu D, Staicu AC, Munteanu MC, Costache M, et al. (2009) Malathion-induced alteration of the antioxidant defence system in kidney, gill, and intestine of Carassiusauratusgibelio. Environ Toxicol 24: 523-530.

26. Giannopolitis CN, Ries SK (1977) Superoxide dismutases: I. Occurrence in higher plants. Plant Physiol 59: 309-314.

27. Sedlak J, Lindsay RH (1968) Estimation of total, protein-bound, and nonprotein sulfhydryl groups in tissue with Ellman's Reagent. Anal Biochem 25: 192-205.

28. Draper HH, Hadley M (1990) Malondialdehyde determination as index of lipid peroxidation. Methods Enzymol 186: 11

29. Bewick V, Cheek L, Ball J (2004) Statistics review 9: one-way analysis of variance. Criti Care 8: 130-136

30. Patel M, Rogers JT, Pane EF, Wood CM (2006) Renal responses to acute lead waterborne exposure in the freshwater rainbow trout (Oncorhynchusmykiss). Aquat Toxicol 80: 362-371.

31. Ozkan-Yilmaz F, Ozluer-Hunt A, Gunduz SG, Berkoz M, Yalin S (2013) Effects of dietary selenium of organic form against lead toxicity on the antioxidant system in Cyprinuscarpio. Fish Physiol Biochem 40: 355-363.

32. Vaglio A, Landriscina C (1999) Changes in liver enzyme activity in the teleost Sparusaurata in response to cadmium intoxication. Ecotoxicol Environ Saf 43: 111-116.

33. Karan V, Vitorovic S, Tutundzic V, Poleksic V (1998) Functional enzymes activity and gill histology of carp after copper sulfate exposure and recovery. Ecotoxicol Environ Saf 40: 49-55.

34. Ulusoy U, Simsek S (2005) Lead removal by polyacrylamide-bentonite and zeolite composites: effect of phytic acid immobilization. J Hazard Mater 127
$163-171$.

35. Aly HA, El-Shitany NA, El-Beshbishy HA, Ashour OM (2013) Ameliorative effect of lycopene against 2,3,7,8-tetrachlorodibenzo-pdioxin- induced rat liver microsomal toxicity: An in vitro study. Toxicollnd Health.

36. Ahmadi A, Mazooji N, Roozbeh J, Mazloom Z, Hasanzade J (2013) Effect of alpha-lipoic acid and vitamin $\mathrm{E}$ supplementation on oxidative stress inflammation, and malnutrition in hemodialysis patients. Iran J Kidney Dis 7: 461-467.

37. Yu CC, Lin JL, Lin-Tan DT (2004) Environmental exposure to lead and progression of chronic renal diseases: a four-year prospective longitudinal study. J Am Soc Nephrol 15: 1016-1022.

38. Upasani CD, Balaraman R (2003) Protective effect of Spirulina on lead induced deleterious changes in the lipid peroxidation and endogenous antioxidants in rats. Phytother Res 17: 330-334.

39. Al-Attar AM (2011) Antioxidant effect of vitamin E treatment on some heavy metals-induced renal and testicular injuries in male mice. Saudi J Biol Sci 18 63-72.

40. Moe SM (2008) Disorders involving calcium, phosphorus, and magnesium Prim Care 35: 215-237.

41. Hsu PC, Guo YL (2002) Antioxidant nutrients and lead toxicity. Toxicology 180 33-44.

42. Farombi EO, Adelowo OA, Ajimoko YR (2007) Biomarkers of oxidative stress and heavy metal levels as indicators of environmental pollution in African cat fish (Clariasgariepinus) from Nigeria Ogun River. Int $\mathrm{J}$ Environ Res Public Health 4: 158-165.

43. Pascoe GA, Olafsdottir K, Reed DJ (1987) Vitamin E protection against chemical-induced cell injury. I. Maintenance of cellular protein thiols as a cytoprotective mechanism. Arch Biochem Biophys 256: 150-158.

44. Rahman K (2007) Studies on free radicals, antioxidants, and co-factors ClinInterv Aging 2: 219-236.

45. Quig D (1998) Cysteine metabolism and metal toxicity. Altern Med Rev 3: 262 270 .

46. Sirota TV (2010) Effect of selenium-containing products on antioxidant enzyme activity in the kidneys, liver, and blood of guinea pigs. Bull Exper Biol Med 149: 412-415.

47. Pryor WA (2000) Vitamin E and heart disease: basic science to clinical intervention trials. Free Radic Biol Med 28:141-164. 